\title{
Production Operations Management of Broom Reed Industry in the Philippines
}

\author{
Kenneth L. Armas and Dr. Rachael R. Moralde
}

\author{
Nueva Ecija University of Science and Technology \\ sir.kennetharmas@gmail.com/rachaelmoralde@gmail.com
}

\begin{abstract}
This study utilized the descriptive method of research. Conducted in municipality of San Antonio province of Nueva Ecija, Philippines. There were 58 participants in the study who are the broom producers in the locality. Structured questionnaire was prepared and served as the main instrument of the study facilitated by an interview of the researchers.

Majority of the producers are 41-50 years of age, male, married and elementary graduate only. Moreover, majority of their enterprises are single proprietorship and operating for more than 11 years. All broom reed enterprises are classified as micro enterprises having an asset of less than Php 3,000,000 and having employees of not more than 10.
\end{abstract}

As to the production process, it was identified that the product of all producers are purely manual. There were no advanced equipment that use electricity and computer in operation. There are various simple tools in the production such as clap or locally called "pang-ipit". Surprisingly, all producers are using their own houses only as the place for production meaning no producer invested in a separate area or building for production. As to the procurement of the raw materials, $86 \%$ of the producers took their main raw materials within the municipality and some other supplies for production.

Based on the result of the study, the producers can produce 31-60 pieces during peak season and 1-15 pieced per day during normal or off-season. Furthermore, the production is decentralized in $98 \%$ of the producers. Indicating that producers split their production processes into various people.

Majority of the producers do not have adequate safety and security measures. They do not have fire extinguishers in the production area considering that the dried tiger grass as the main raw materials is flammable though all of them prohibit smoking in the area. All producers have their own quality inspection of the final output. Quality inspection is usually done by the owner or other member of the family designated also as supervisor. Relative to this, $40 \%$ of the producers normally do not have defective units in the production. Majority of the producers have their own waste disposal method through burning of some excess and unusable supplies and materials.

Based on the survey-interview conducted by the researchers, the common problems encountered by the producers are having lack of funds of capital for the production and further investments. They also feel that there is lack of assistance and attention coming from the local government units through different programs, relevant policies and subsidies.

The researchers were able to arrive to a One-Year Strategic Action Plan for the industry. The plan was presented to the local government unit for appropriate actions. Significant programs included are giving technical assistance to the producers in improving their practices in production. Modernization of the production process was proposed to increase the number of the units produced and improve the quality of the outputs. Also, organization of the producers into a cooperative will help them to improve their ability to market and promote their products not only in the municipality but also in the country and eventually internationally. The local government units can also implement interventions by; (1) finding possible financing institutions for the producers, (2) improving the promotion of the industry through different activities that can attract investors and tourists, (3) giving subsidies in the raw materials, (4) expansion of the production area of the tiger grass in the municipality to increase the supply thus will reduce the cost of the raw materials of the producers, and (5) giving tax incentives for the producers.

The researchers also recommend further studies relative to this to understand deeper the industry and identify other problems to be resolved specially in the areas of marketing and organization management. Personal and family values of the producers and employees can also be studied to determine the possible relationship of these factors to the performance of the broom reed enterprises.

Keywords-Broom Reed, Local Industry in Philippines, Production Operations Management. 


\section{INTRODUCTION}

In the Philippines, the traditional broom called broom reed, "walistambo" in the local language, serves as the most common cleaning tool in the country for a long time. This tool may be simple yet important consideration in every household. This broom reed is made of an indigenous and wild grass called tiger grass (thysaolaena maxima), locally known as "tambo" in the Philippine language. As hedgegrow, the species helped control soil erosion while helping conserve water. As raw material for soft broom production, it provided potential livelihood to upland farmers due to increasing demand for tiger grass made brooms (PCAARD, 2010).

This wild grass grows as high as 2.5 meters and can thrive at low to medium elevations but can grow faster in higher elevation. Normally, it grows in open areas particularly in logged-over areas, mountain slopes and ravines.

Tiger grass is being propagated by upland farmers in some parts of Benguet Province. Likewise, it grows abundantly in the highland areas of Ifugao and Mt. Province. It can be grown in many types of soils such as clay, sandy clay loam and sandy loam.

In the Philippines, the production of broom reed serves as a main livelihood for many households especially in the municipality of San Antonio province of Nueva Ecija. In fact, the municipality is celebrating an annual festival for walistambo (local name of broom reed) through street dance competition and trade fair. The local government unit had been promoting the commercialization of tiger grass production to boost the broom industry and enhance the identity and pride of the municipality. This project was implemented under the Community Livelihood Assistance Special Program (CLASP) in partnership with local government units and other people's organization (Pinoy Entrepreneur, 2011).

Since the production of broom reed is the main livelihood in the municipality and the authors can see potential for business operation development, the researchers conducted this study to assess the current production operations management practices of broom reed producers in the locality. Also, the study determined the current challenges encountered by the producers to determine also the possible proposed programs for the Development Plan of the industry.

\section{OBJECTIVES OF THE STUDY}

This study explored the production operations management of broom reed industry in the Philippines. Specifically, this study sought to identify the following:

1. Profile of the Producers;
2. Profile of the Enterprises;

3. Production Management Practices;

4. Internal And External Problems Encountered by the Producers; and

5. Programs for the Strategic Action Plan for the Industry.

\section{METHODOLOGY}

The descriptive design was utilized to explore the production operations management of 58 broom reed enterprises from the different barangays in San Antonio, Nueva Ecija, Philippines. The researchers used two probability samplings to identify the respondents, specifically cluster random sampling to identify the barangays to include then stratified random sampling. Structured questionnaire served as the main instrument of the study facilitated with interviews to the respondents.

\section{RESULTS AND DISCUSSION}

\subsection{Profile of the Owner}

Table.1: Distribution of Respondents According to Age

\begin{tabular}{|l|c|c|}
\hline \multicolumn{1}{|c|}{ Age } & Frequency & Percentage \\
\hline $\begin{array}{l}\text { Below 20 } \\
\text { years old }\end{array}$ & 2 & $3 \%$ \\
\hline $\begin{array}{l}\text { 21-30 years } \\
\text { old }\end{array}$ & 8 & $14 \%$ \\
\hline $\begin{array}{l}\text { 31-40 years } \\
\text { old }\end{array}$ & 13 & $23 \%$ \\
\hline $\begin{array}{l}\text { 41-50 years } \\
\text { old }\end{array}$ & 24 & $41 \%$ \\
\hline $\begin{array}{l}\text { 51-60 years } \\
\text { old }\end{array}$ & 9 & $3 \%$ \\
\hline $\begin{array}{l}\text { 61 years and } \\
\text { above }\end{array}$ & 2 & $\mathbf{1 0 0 \%}$ \\
\hline \multicolumn{2}{|c|}{ TOTAL } & $\mathbf{5 8}$ \\
\hline
\end{tabular}

The table above shows that majority of the respondents is in the age bracket of 41-50 years old. Whereas, $23 \%$ are in the age bracket of 31-40 years old, $16 \%$ are belong to $51-60$ years old, $14 \%$ are in $21-30$ years old.

Most of the respondents engaged in the manufacturing of walis-tambo belonged to the generation of baby boomers where these were people who wanted to build a perfect career and stability in life. Furthermore, for them experience matters and that came with age. 
Table.2: Distribution of Respondents According to Gender

\begin{tabular}{|l|c|c|}
\hline Gender & Frequency & Percentage \\
\hline Male & 49 & $84 \%$ \\
\hline Female & 9 & $16 \%$ \\
\hline TOTAL & $\mathbf{5 8}$ & $\mathbf{1 0 0 \%}$ \\
\hline
\end{tabular}

The table above shows that 49 out of 58 respondents were male which was higher than the total female respondents. This means that more entrepreneurs who established their own business were men with chances of $84 \%$.

The result also shows that most of the people who wanted to engage in such businesses were men. It can be interpreted as that men have more specialization in dealing with the works required in managing this kind of industry.

Table.3: Distribution of Respondents According to Marital Status

\begin{tabular}{|l|c|c|}
\hline \multicolumn{1}{|c|}{ Status } & Frequency & Percentage \\
\hline Single & 10 & $17 \%$ \\
\hline Married & 48 & $83 \%$ \\
\hline TOTAL & $\mathbf{5 8}$ & $\mathbf{1 0 0 \%}$ \\
\hline
\end{tabular}

The Table 3 shows the marital status of the respondents. The result shows that majority of the respondents are married having a percentage of $83 \%$ while the remaining $17 \%$ are single.

Table.4: Distribution of Respondents According to Educational Attainment

\begin{tabular}{|l|c|c|}
\hline \multicolumn{1}{|c|}{$\begin{array}{c}\text { Educational } \\
\text { Background }\end{array}$} & Frequency & Percentage \\
\hline $\begin{array}{l}\text { Elementary } \\
\text { graduate }\end{array}$ & 32 & $55 \%$ \\
\hline $\begin{array}{l}\text { High School } \\
\text { Graduate }\end{array}$ & 17 & $30 \%$ \\
\hline $\begin{array}{l}\text { College } \\
\text { Undergraduate }\end{array}$ & 3 & $5 \%$ \\
\hline $\begin{array}{l}\text { College } \\
\text { Graduate }\end{array}$ & $\mathbf{5 8}$ & $\mathbf{1 0 0 \%}$ \\
\hline TOTAL &
\end{tabular}

The table above indicates the highest level of education the broom reed enterprise owners had obtained. Majority of the respondents who have been interviewed were elementary graduates with a frequency of $32 \%$, and with a percentage of $55 \%$. This implies that engaging in the industry does not require any educational qualifications and particular college degree.
3.2. Profile of the Enterprise

Table.5: Distribution of Respondents According to Business

\begin{tabular}{|l|c|c|}
\hline \multicolumn{1}{|c|}{ Ownership } \\
$\begin{array}{c}\text { Type of } \\
\text { Ownership }\end{array}$ & Frequency & Percentage \\
\hline $\begin{array}{l}\text { Single } \\
\text { Proprietorship }\end{array}$ & 47 & $81 \%$ \\
\hline Partnership & 11 & $19 \%$ \\
\hline TOTAL & $\mathbf{5 8}$ & $\mathbf{1 0 0 \%}$ \\
\hline
\end{tabular}

Table 5 shows the frequency and percentage of the type of ownership of broom industry in San Antonio. Among the 58 respondents, $81 \%$ were single proprietorship and $19 \%$ were partnership. The result shows that most of the broom producers were single proprietorship where the number of owner was only one (1). It was for the reason that single proprietorship was the easiest to organize.

Table.6: Distribution of Respondents According to Years of Existence

\begin{tabular}{|l|c|c|}
\hline $\begin{array}{c}\text { Years of } \\
\text { Existence }\end{array}$ & Frequency & Percentage \\
\hline $1-5$ years & 2 & $3 \%$ \\
\hline $\begin{array}{l}6-10 \\
\text { years }\end{array}$ & 5 & $9 \%$ \\
\hline $\begin{array}{l}11 \text { years } \\
\text { above }\end{array}$ & 51 & $88 \%$ \\
\hline TOTAL & $\mathbf{5 8}$ & $\mathbf{1 0 0 \%}$ \\
\hline
\end{tabular}

Table 6 shows the frequency and percentage of the years of existence of broom industry in San Antonio. Among the 58 respondents, $88 \%$ have been operating for more than 11 years, nine percent $(9 \%)$ are already existing from 6-10 years in the industry and three percent $(3 \%)$ operating for 1-5 year. It indicates that most of the broom reed manufacturers were operating for more than eleven years and expecting to operate more than the result of the study.

Table.7: Distribution of Respondents According to Number of Workers (Peak Season)

\begin{tabular}{|l|c|c|}
\hline $\begin{array}{c}\text { Peak } \\
\text { Season }\end{array}$ & Frequency & Percentage \\
\hline $1-5$ & 41 & $71 \%$ \\
\hline $6-10$ & 15 & $26 \%$ \\
\hline $11-15$ & 2 & $3 \%$ \\
\hline TOTAL & $\mathbf{5 8}$ & $\mathbf{1 0 0 \%}$ \\
\hline
\end{tabular}


Table 7 shows the number of workers during peak season. Seventy-one percent $(71 \%)$ of the producers employs 1-5 workers, $26 \%$ employs 6-10 workers and three percent $(3 \%)$ employs 11-15 workers. Result shows that most of the broom reed producers employed 1-5 workers during peak season where the demand on the product was higher than the normal season.

Table.8: Distribution of Respondents According to Number of Workers (Off- Season)

\begin{tabular}{|l|c|c|}
\hline $\begin{array}{c}\text { Off } \\
\text { Season }\end{array}$ & Frequency & Percentage \\
\hline $\begin{array}{l}\text { Les } s \\
\text { than } 5\end{array}$ & 50 & $86 \%$ \\
\hline $6-10$ & 8 & $14 \%$ \\
\hline TOTAl & $\mathbf{5 8}$ & $100 \%$ \\
\hline
\end{tabular}

Table 8 shows the number of workers during offseason. Eighty-six percent $(86 \%)$ of the producers employed less than 5 workers, and $14 \%$ employ 6-10 workers. Furthermore, the result shows that $86 \%$ of the broom reed producers employing less than 5 workers during off-season where the demand on the product is lower than the normal.

Table.9: Distribution of Respondents According to Size of the Enterprise

\begin{tabular}{|l|c|c|}
\hline \multicolumn{1}{|c|}{ Size of the Enterprise } & Frequency & Percentage \\
\hline $\begin{array}{l}\text { Micro Enterprises } \\
\text { (Assets of Less than Php } \\
3,000,000)\end{array}$ & 58 & $100 \%$ \\
\hline $\begin{array}{l}\text { Small Enterprises } \\
\text { (Assets of Php 3,000,001 } \\
\text { to Php 15,000,000) }\end{array}$ & 0 & 0 \\
\hline $\begin{array}{l}\text { Medium Enterprises } \\
\text { Assets of Php } \\
\begin{array}{l}15,000,001 \text { to Php } \\
100,000,000)\end{array}\end{array}$ & 0 & 0 \\
\hline $\begin{array}{l}\text { Large Enterprises } \\
\text { (More than Php } \\
100,000,000)\end{array}$ & 0 & 0 \\
\hline \multicolumn{1}{|c|}{ TOTAL } & $\mathbf{5 8}$ & $\mathbf{1 0 0 \%}$ \\
\hline
\end{tabular}

The Table 9 shows the size of the broom reed enterprises according to the size. The classification used was based on the Republic Act 9501 or the Magna Carta for Micro, Small and Medium Enterprises of the Philippines.

The table shows the size of the enterprise as of August 2017 where all of the respondents or owner was belong to Micro
Enterprises which the total of the assets were less than Php $3,000,000.00$.

\subsection{Production and Operations Management Practices} Table.10: Methods of Production

\begin{tabular}{|l|l|l|}
\hline Methods of Production & Frequency & Percentage \\
\hline Purely Manual & 58 & $100 \%$ \\
\hline Partially Mechanized & 0 & 0 \\
\hline Fully Mechanized & 0 & 0 \\
\hline Others & 0 & 0 \\
\hline TOTAL & 58 & $100 \%$ \\
\hline
\end{tabular}

The above table represents the methods of production used by broom reed enterprises in the locality.It shows that the method of production of broom reed producers was purely manual, they are not using any kind of electronic machines or tools to produce their outputs.

Table.11: Tools Used in Production

\begin{tabular}{|l|c|c|}
\hline \multicolumn{1}{|c|}{ Tools Used } & Frequency & Percentage \\
\hline Balibol & 22 & $38 \%$ \\
\hline Dangat & 28 & $48 \%$ \\
\hline Panuot & 55 & $95 \%$ \\
\hline Pang-ipit & 58 & $100 \%$ \\
\hline Others & 0 & 0 \\
\hline TOTAL & $\mathbf{5 8}$ & $\mathbf{1 0 0 \%}$ \\
\hline
\end{tabular}

The table 11 shows the tools used in making broom reed. All the respondents were using pang-ipit, 95\% were using panuot, $48 \%$ used dangat and only $38 \%$ usedbalibol. This means that pang-ipit was the most commonly used tool of all the makers of broom reed.

Table.12: Place of Production

\begin{tabular}{|l|c|c|}
\hline \multicolumn{1}{|c|}{$\begin{array}{c}\text { Place of } \\
\text { Production }\end{array}$} & Frequency & Percentage \\
\hline Owner's home & 58 & $100 \%$ \\
\hline $\begin{array}{l}\text { Separate owned } \\
\text { production building }\end{array}$ & 0 & 0 \\
\hline $\begin{array}{l}\text { Leased space or } \\
\text { building }\end{array}$ & 0 & 0 \\
\hline Others & 0 & 0 \\
\hline TOTAL & $\mathbf{5 8}$ & $\mathbf{1 0 0 \%}$ \\
\hline
\end{tabular}

The table below shows the place of production being utilized by the producers. All producers The table 12 shows the place of production in producing broom reed. All of the producers used their home as a place of production. All of the owners used their vacant space in their home like garage and terrace to produce broom reed. 
Table.13: Procurement of Raw Materials Panicles

\begin{tabular}{|l|c|c|}
\hline \multicolumn{1}{|c|}{ Panicles } & Frequency & Percentage \\
\hline $\begin{array}{l}\text { Within San } \\
\text { Antonio }\end{array}$ & 50 & $86 \%$ \\
\hline $\begin{array}{l}\text { Within the } \\
\text { Province }\end{array}$ & 0 & 0 \\
\hline $\begin{array}{l}\text { Within the } \\
\text { Region }\end{array}$ & 0 & 0 \\
\hline $\begin{array}{l}\text { Outside the } \\
\text { Region }\end{array}$ & 8 & $\mathbf{1 0 0 \%}$ \\
\hline TOTAL & $\mathbf{5 8}$ & \\
\hline
\end{tabular}

The table above shows that out of 58 respondents, $86 \%$ of them took their main raw materials in producing broom reed which was panicles from San Antonio, while the remaining fourteen $14 \%$ came from other place like Baguio and Bicol.

Table.14: Procurement of Raw materials Bikal/Tabla

\begin{tabular}{|l|c|c|}
\hline \multicolumn{1}{|c|}{ Bikal/Tabla } & Frequency & Percentage \\
\hline Within San Antonio & 21 & $36 \%$ \\
\hline $\begin{array}{l}\text { Within the Province } \\
\text { (except San Antonio) }\end{array}$ & 0 & 0 \\
\hline Within the Region & 12 & $12 \%$ \\
\hline Metro Manila & 1 & $2 \%$ \\
\hline Others & 29 & $50 \%$ \\
\hline Total & $\mathbf{5 8}$ & $\mathbf{1 0 0 \%}$ \\
\hline
\end{tabular}

The table above shows that out of 58 respondents, $36 \%$ of them took their raw materials called bikal/tabla from San Antonio, six percent $(6 \%)$ came from Bulacan and the another six percent $(6 \%)$ came from Bataan, the other two percent $(2 \%)$ came from Metro Manila and Bicol while the remaining $50 \%$ were from other places. It means that majority of raw materials called Bikal/Tabla came from other places like Cavite and Laguna.

Table.15: Procurement of Raw Materials Sticker

\begin{tabular}{|c|c|c|}
\hline Plastic/Straw & Frequency & Percentage \\
\hline Within San Antonio & 55 & $95 \%$ \\
\hline Within the Province & 0 & 0 \\
\hline Within the Region & 0 & 0 \\
\hline Metro Manila & 3 & $5 \%$ \\
\hline Others & 0 & 0 \\
\hline TOTAL & 58 & $100 \%$ \\
\hline
\end{tabular}

Table 15 shows the procurement of sticker as a raw material in making broom reed. Ninety-five percent $(95 \%)$ get stickers in San Antonio and the remaining five percent $(5 \%)$ acquired in Metro Manila. The result shows that most of the producers obtained stickers in San Antonio.

Table.16: Procurement of Raw Materials Plastic/Straw

\begin{tabular}{|l|c|c|}
\hline Plastic/Straw & Frequency & Percentage \\
\hline $\begin{array}{l}\text { Within San } \\
\text { Antonio }\end{array}$ & 55 & $95 \%$ \\
\hline $\begin{array}{l}\text { Within the } \\
\text { Province }\end{array}$ & 0 & 0 \\
\hline $\begin{array}{l}\text { Within the } \\
\text { Region }\end{array}$ & 0 & 0 \\
\hline Metro Manila & 3 & $5 \%$ \\
\hline Others & 0 & 0 \\
\hline TOTAL & 58 & $100 \%$ \\
\hline
\end{tabular}

The table 16 shows that out of 58 respondents, majority of them that has a frequency of 55 and with a rate of $95 \%$, producers took the raw materials called plastic or straw within San Antonio, while the remaining five percent (5\%) were came from Metro Manila. So it means that majority of the respondents obtained their raw materials called plastic in San Antonio.

Table.17: Number of Brooms Produced per Day (Peak Season)

\begin{tabular}{|l|c|c|}
\hline \multicolumn{1}{|c|}{ Peak Season } & Frequency & Percentage \\
\hline $1-30$ pieces & 22 & $38 \%$ \\
\hline $31-60$ pieces & 25 & $43 \%$ \\
\hline $61-90$ pieces & 1 & $2 \%$ \\
\hline $91-120$ pieces & 0 & 0 \\
\hline $121-150$ pieces & 10 & $17 \%$ \\
\hline TOTAL & $\mathbf{5 8}$ & $\mathbf{1 0 0 \%}$ \\
\hline
\end{tabular}

This table shows the number of broom produced per day during peak season. Forty-three percent $(43 \%)$ of the producers produced 31-60 pieces per day, $36 \%$ produced $1-30$ pieces, and $17 \%$ produced $121-150$ pieces. It implies that most of the producers, produced $31-60$ pieces a day, it was good enough to achieve the desired demand during peak season.

Table.18: Number of Brooms Produced per Day (OffSeason)

\begin{tabular}{|l|c|c|}
\hline $\begin{array}{c}\text { Number of Production } \\
\text { Output }\end{array}$ & Frequency & Percentage \\
\hline $1-15$ pieces & 33 & $57 \%$ \\
\hline $16-30$ pieces & 21 & $36 \%$ \\
\hline $31-45$ pieces & 0 & 0 \\
\hline
\end{tabular}




\begin{tabular}{|l|c|c|}
\hline $46-60$ pieces & 0 & 0 \\
\hline $61-75$ pieces & 1 & $2 \%$ \\
\hline $76-90$ pieces & 2 & $3 \%$ \\
\hline $91-105$ pieces & 0 & 0 \\
\hline 106 pieces and above & 1 & $2 \%$ \\
\hline TOTAL & $\mathbf{5 8}$ & $\mathbf{1 0 0 \%}$ \\
\hline
\end{tabular}

extinguishers and two percent (2\%) have first aid kit. The result shows that most of the broom producers have "No Smoking Policy", which was better to this kind of business because most of the raw materials used in production were prone to fire.

Table.21: Standardization of Output/Product

This table shows the number of broom produced per day during off season. Forty-three percent $(43 \%)$ of the producers produced $31-45$ pieces per day, $36 \%$ produces 1 30 pieces and $17 \%$ produces $121-150$ pieces. It indicates that most of broom reed producers produced 31-60 pieces; it was enough to fulfil the demand during off season.

Table.19: Production Utilization

\begin{tabular}{|l|l|l|}
\hline $\begin{array}{l}\text { Production } \\
\text { Utilization }\end{array}$ & Frequency & Percentage \\
\hline Centralized & 1 & $2 \%$ \\
\hline Decentralized & 57 & $98 \%$ \\
\hline TOTAL & 58 & $100 \%$ \\
\hline
\end{tabular}

Table 19 describes the production utilization of broom reed producers. Ninety-eight percent (98\%) of them have decentralized production while the remaining two percent $(2 \%)$ have centralized production.

The result shows that the production of broom reed producers was decentralized where the managerial approach of dispersion of authority throughout to enable the workers at all levels play assigned roles optimally (Office Management and Essential Business Correspondence).

Table.20: Security and Safety Measures

\begin{tabular}{|l|c|c|}
\hline $\begin{array}{c}\text { Security and Safety } \\
\text { measures }\end{array}$ & Frequency & Percentage \\
\hline $\begin{array}{l}\text { Presence of fire } \\
\text { extinguishers }\end{array}$ & 2 & $3 \%$ \\
\hline $\begin{array}{l}\text { Wearing of masks in } \\
\text { the production area }\end{array}$ & 3 & $5 \%$ \\
\hline First aid kit & 1 & $2 \%$ \\
\hline Security guards & 0 & 0 \\
\hline No smoking policy & 52 & $90 \%$ \\
\hline \multicolumn{1}{|c|}{ TOTAL } & $\mathbf{5 8}$ & $\mathbf{1 0 0 \%}$ \\
\hline
\end{tabular}

This table shows the frequency and percentage of security and safety measures implemented by broom reed producers. Ninety percent $(90 \%)$ have no smoking policy, five percent $(5 \%)$ implemented wearing of mask in the production area, three percent (3\%) have presence of fire

\begin{tabular}{|c|c|c|}
\hline $\begin{array}{c}\text { Standard of } \\
\text { Output/Product }\end{array}$ & Frequency & Percentage \\
\hline The product has standards & 58 & $100 \%$ \\
\hline The product has no standards & 0 & 0 \\
\hline TOTAL & 58 & $100 \%$ \\
\hline
\end{tabular}

This table represents the standardization of output/product of broom reed producers where all of the producers have standards to their products which was better to all business not even like this kind of business but of course to other businesses, because for the researchers, standard or quality of the product was the image of the business, and this was the way on how to satisfy the needs and wants of customers.

Table.22: Average Spoiled and Defective Brooms per Day

\begin{tabular}{|c|c|c|}
\hline $\begin{array}{c}\text { Average Spoiled And } \\
\text { Defective Brooms } \\
\text { Per Day }\end{array}$ & Frequency & Percentage \\
\hline None & 23 & $40 \%$ \\
\hline $1-5$ pieces & 20 & $34 \%$ \\
\hline $6-10$ pieces & 4 & $7 \%$ \\
\hline $11-15$ pieces & 8 & $14 \%$ \\
\hline $16-20$ pieces & 3 & $5 \%$ \\
\hline TOTAL & $\mathbf{5 8}$ & $\mathbf{1 0 0 \%}$ \\
\hline
\end{tabular}

This table shows the number of average and spoiled defective brooms per day. Forty percent (40\%) had no defective units, $34 \%$ have $1-4$ pieces, $14 \%$ had $11-15$ pieces, seven percent (7\%) have 6-10 pieces and five percent (5\%) have $16-20$ pieces of defective units per day. It indicated that majority of the producers which was $40 \%$ of broom producers have no spoiled and defective output/product produced per day which was better because it means that in this kind of business, every materials used have importance.

Table.23: Waste Management

\begin{tabular}{|l|l|l|}
\hline Waste Management & Frequency & Percentage \\
\hline
\end{tabular}




\begin{tabular}{|c|c|c|}
\hline $\begin{array}{c}\text { Have own waste } \\
\text { disposal method }\end{array}$ & 55 & $95 \%$ \\
\hline $\begin{array}{c}\text { Waste collected by } \\
\text { garbage collector }\end{array}$ & 3 & $5 \%$ \\
\hline TOTAL & $\mathbf{5 8}$ & $\mathbf{1 0 0 \%}$ \\
\hline
\end{tabular}

This table shows the waste management of broom reed producers. Ninety-five percent (95\%) of them have their own waste disposal method and five percent $(5 \%)$ have their waste collected by garbage collector. This indicates that $95 \%$ of the broom reed producers have their own waste disposal method which was enough to prove that the respondents were knowledgeable on how to contribute to the Clean and Green Program.

\subsection{Problems Encountered in the Operation}

The following results are the identified internal and external problems in the operation of the broom reed enterprises. Problems ware rated using likert-scale whereas one is the lowest and five is the highest.

Table.24: Internal Problems Encountered

\begin{tabular}{|cl|c|c|}
\hline \multicolumn{1}{|c|}{$\begin{array}{c}\text { Internal Problems } \\
\text { Encountered }\end{array}$} & $\begin{array}{c}\text { Weigh } \\
\text { ted } \\
\text { Mean }\end{array}$ & $\begin{array}{c}\text { Verbal } \\
\text { Interpretati } \\
\text { on }\end{array}$ \\
\hline 1. & Lack of funds & 4.63 & Always \\
\hline 2. & $\begin{array}{l}\text { Lack of strategic } \\
\text { marketing plan }\end{array}$ & 3.54 & Very Often \\
\hline 3. & $\begin{array}{l}\text { Lack of upgraded } \\
\text { equipments and machines }\end{array}$ & 2.82 & Often \\
\hline 4. & $\begin{array}{l}\text { Lack of management } \\
\text { expertise }\end{array}$ & 3.23 & Often \\
\hline 5. & $\begin{array}{l}\text { Values and attitude of the } \\
\text { workers }\end{array}$ & 1.61 & Sometimes \\
\hline 6. & Limited supply & 2.27 & Sometimes \\
\hline 7. & Small production area & 3.25 & Often \\
\hline 8. & Lack of trained workers & 2.02 & Sometimes \\
\hline 9. & $\begin{array}{l}\text { High rate of defective or } \\
\text { spoiled output }\end{array}$ & 1.43 & Never \\
\hline & $\begin{array}{l}\text { 10.Waste disposal and } \\
\text { management }\end{array}$ & 1.34 & Never \\
\hline
\end{tabular}

Table 24 shows the internal problems encountered by broom reed producers. The respondents always encountered lack of funds. They also encountered lack of management expertise very often. They often lack of strategic marketing plan and upgraded equipments and machines as well as the small production area. Sometimes, they encountered limited supply due to limited funds. Furthermore, they never encountered problems about the values and attitude of the workers, lack of trained workers, high rate of defective or spoiled output and waste disposal and management.

This means that broom reed producers always encountered internal problem such as lack of funds which has a huge impact to the business since funds was one of the major reasons why businesses exist.

Table.25: External Problems Encountered

\begin{tabular}{|c|c|c|}
\hline $\begin{array}{c}\text { External Problems } \\
\text { Encountered }\end{array}$ & $\begin{array}{l}\text { Weighted } \\
\text { Mean }\end{array}$ & $\begin{array}{c}\text { Verbal } \\
\text { Interpretation }\end{array}$ \\
\hline 1. Seasonal demand & 2.82 & Often \\
\hline $\begin{array}{l}\text { 2. Lack of as sistance, } \\
\text { programs and } \\
\text { policies from the } \\
\text { LGU }\end{array}$ & 4.55 & Always \\
\hline $\begin{array}{l}\text { 3. Unstable prices of } \\
\text { raw materials }\end{array}$ & 3.48 & Often \\
\hline $\begin{array}{l}\text { 4. } \begin{array}{l}\text { High level of } \\
\text { competition }\end{array} \\
\text { compla }\end{array}$ & 3.54 & Very Often \\
\hline $\begin{array}{l}\text { 5. Predatory pricing by } \\
\text { competitors }\end{array}$ & 2.96 & Often \\
\hline 6. $\quad$ Fragmented market & 2.95 & Often \\
\hline 7. Power interruptions & 1.11 & Never \\
\hline $\begin{array}{l}\text { 8. Limited supplies of } \\
\text { raw materials during } \\
\text { peak season }\end{array}$ & 2.32 & Sometimes \\
\hline $\begin{array}{l}\text { 9. } \\
\text { Lack of manpower } \\
\text { especially during } \\
\text { peak season }\end{array}$ & 3.36 & Often \\
\hline $\begin{array}{l}\text { 10.Absence of broom } \\
\text { producers cooperatives or } \\
\text { organizations }\end{array}$ & 3.68 & Very Often \\
\hline
\end{tabular}

Table 25 shows the external problems encountered by broom reed producers. The respondents always encountered problems like lack of assistance, programs, and policies from the Local Government Unit (LGU). The respondents very often encountered high level of competition as well as lack of manpower especially during peak season. They often run into seasonal demand, unstable prices of raw materials, predatory pricing by competitors, fragmented market and absence of broom producers cooperatives or organizations. Sometimes, they encountered limited supplies of raw materials during peak season. Moreover, they never encountered problems with power interruptions.

The result shows that broom reed producers always encountered external problem such as lack of assistance, 
programs, and policies from the Local Government Unit (LGU).

\section{SUMMARY OF FINDINGS, CONCLUS ION AND RECOMMENDATIONS}

\subsection{Summary of Findings}

Majority of the producers are 41-50 years of age, male, married and elementary graduate only. Moreover, majority of their enterprises are single proprietorship and operating for more than 11 years. All broom reed enterprises are classified as micro enterprises having an asset of less than Php 3,000,000 and having employees of not more than 10.

As to the production process, it was identified that the product of all producers are purely manual. There were no advanced equipment that use electricity and computer in operation. There are various simple tools in the production such as clap or locally called "pang-ipit". Surprisingly, all producers are using their own houses only as the place for production meaning no producer invested in a separate area or building for production. As to the procurement of the raw materials, $86 \%$ of the producers took their main raw materials within the municipality and some other supplies for production.

Based on the result of the study, the producers can produce 31-60 pieces during peak season and 1-15 pieced per day during normal or off-season. Furthermore, the production is decentralized in $98 \%$ of the producers. Indicating that producers split their production processes into various people.

Majority of the producers do not have adequate safety and security measures. They do not have fire extinguishers in the production area considering that the dried tiger grass as the main raw materials is flammable though all of them prohibit smoking in the area. All producers have their own quality inspection of the final output. Quality inspection is usually done by the owner or other member of the family designated also as supervisor. Relative to this, $40 \%$ of the producers normally do not have defective units in the production. Majority of the producers have their own waste disposal method through burning of some excess and unusable supplies and materials.

Based on the survey-interview conducted by the researchers, the common problems encountered by the producers are having lack of funds of capital for the production and further investments. They also feel that there is lack of assistance and attention coming from the local government units through different programs, relevant policies and subsidies.

\subsection{Conclusion}

The industry of broom reed in the Philippines serves as a main livelihood for many families especially in the municipality of San Antonio, Nueva Ecija. From the traditional wild grass, tiger grass, filipinos developed a useful cleaning tools for every household. Since then, different efforts had been made to support the producers. The local government unit of San Antonio, use the broom reed, locally known as walistambo", as an identity or trademark for the municipality. But this study shows that there are areas that need to be improved and problems that need to be addressed.

Most of the producers are still infant and classified as micro enterprises having assets of not more than Php 3,000,000. Also, they do not have enough facilities for the production and they are not able to hire additional employees to increase the production. Furthermore, small production can be attributed to the method that the producers are currently using. All of them are purely manual in producing broom reed. If they can improve the production process by adding advanced equipment, production output can definitely increase. Producers are also vulnerable to different problems, internally and externally. Just like other micro enterprises, broom reed producers can also encounter insufficiency in funds and capital.

For these reasons the researchers were able to arrive to different programs for a One Year Strategic Development Plan for the industry. The development plan was submitted to the local government unit of San Antonio for their appropriate actions. 


\section{A ONE YEAR STRATEGIC ACTION PLAN FOR WALIS-TAMBO INDUSTRY IN SAN ANTONIO, NUEVA ECIJA}

Main Objective: To strengthen the industry of walis-tambo in San Antonio, Nueva Ecija from the production to distribution.

\begin{tabular}{|c|c|c|c|c|}
\hline PLANS & OBJECTIVES & ACTIVITIES/STRATEGIES & $\begin{array}{l}\text { PERSONS/ } \\
\text { AGENCIES } \\
\text { INVOLVED }\end{array}$ & $\begin{array}{c}\text { TARGET } \\
\text { IMPLEMENTATI } \\
\text { ON DATE }\end{array}$ \\
\hline $\begin{array}{l}\text { Improve the } \\
\text { promotion of } \\
\text { the walis-tambo } \\
\text { made in the } \\
\text { municipality. }\end{array}$ & $\begin{array}{l}\text { To improve the target } \\
\text { market awareness on the } \\
\text { product of the municipality }\end{array}$ & $\begin{array}{l}\text { 1. Use the name of the San Antonio in } \\
\text { the sticker of the brooms rather than } \\
\text { Baguio City } \\
\text { 2. Encourage sales promotions such as } \\
\text { quantity and trade discounts to } \\
\text { penetrate the target market to buy in } \\
\text { large quantity }\end{array}$ & $\begin{array}{l}\text { Manufacturers } \\
\text { and LGU }\end{array}$ & March 2018 \\
\hline $\begin{array}{l}\text { Organization of } \\
\text { Multi-Purpose } \\
\text { Cooperatives in } \\
\text { the } \\
\text { Municipality }\end{array}$ & $\begin{array}{c}\text { To improve the } \\
\text { production and } \\
\text { distribution of each } \\
\text { manufacturers. } \\
\text { To control the pricing, } \\
\text { design, and distribution of } \\
\text { the manufacturers. }\end{array}$ & $\begin{array}{l}\text { 1. Formation of the walis-tambo } \\
\text { multi-purpose cooperatives in the } \\
\text { municipality } \\
\text { 2. Encourage manufacturers to join } \\
\text { the cooperatives }\end{array}$ & $\begin{array}{c}\text { LGU, } \\
\text { Manufacturers } \\
\text {, Municipal } \\
\text { Agricultural } \\
\text { Office }\end{array}$ & March 2018 \\
\hline $\begin{array}{l}\text { Strengthening } \\
\text { the annual } \\
\text { walis-tambo } \\
\text { festival of the } \\
\text { municipality }\end{array}$ & $\begin{array}{l}\text { To promote the industry } \\
\text { and the municipality. }\end{array}$ & $\begin{array}{l}\text { 1. Creating festival-related programs } \\
\text { featuring walis-tambo such as } \\
\text { street dance competition, trade } \\
\text { fairs, etc. }\end{array}$ & $\begin{array}{c}\text { LGU, } \\
\text { Manufacturers }\end{array}$ & October 2018 \\
\hline $\begin{array}{l}\text { Standardization } \\
\text { of the products }\end{array}$ & $\begin{array}{l}\text { To standardize the output } \\
\text { of the producers to control } \\
\text { spoilage and defective } \\
\text { units. }\end{array}$ & $\begin{array}{l}\text { 1. Setting standards on weight, size, } \\
\text { height, and width of the products. }\end{array}$ & $\begin{array}{c}\text { LGU, DTI, } \\
\text { and } \\
\text { Manufacturers }\end{array}$ & March 2018 \\
\hline $\begin{array}{l}\text { Price control for } \\
\text { the } \\
\text { manufacturers }\end{array}$ & $\begin{array}{l}\text { To control the pricing for } \\
\text { the manufacturers to avoid } \\
\text { predatory pricing. }\end{array}$ & $\begin{array}{l}\text { 1. Setting price floor and price ceiling } \\
\text { for the products. }\end{array}$ & $\begin{array}{c}\text { DIT, LGU, } \\
\text { and } \\
\text { Manufacturers }\end{array}$ & March 2018 \\
\hline $\begin{array}{l}\text { Free trainings } \\
\text { for the out-of- } \\
\text { school youth } \\
\text { and } \\
\text { unemployed } \\
\text { individuals in } \\
\text { the production } \\
\text { of walis-tambo }\end{array}$ & $\begin{array}{l}\text { To solve the manpower } \\
\text { shortage of the } \\
\text { manufacturers especially } \\
\text { during peak season. } \\
\text { To avoid unethical } \\
\text { practices of the } \\
\text { manufacturers related to } \\
\text { human resources such as } \\
\text { pirating. }\end{array}$ & $\begin{array}{l}\text { 1. Giving free trainings in the } \\
\text { production of walis-tambo to out- } \\
\text { of-school youth and other } \\
\text { individuals in the municipality. }\end{array}$ & $\begin{array}{c}\text { LGU, DTI, } \\
\text { Manufacturers }\end{array}$ & May 2018 \\
\hline $\begin{array}{l}\text { Financing } \\
\text { programs for } \\
\text { the } \\
\text { manufacturers }\end{array}$ & $\begin{array}{l}\text { To provided financing } \\
\text { services for the } \\
\text { manufacturers which } \\
\text { considered as one of the } \\
\text { major problem of the } \\
\text { industry }\end{array}$ & $\begin{array}{l}\text { 1. Providing financing assistance for } \\
\text { the manufacturers from the LGU and } \\
\text { different financing institutions }\end{array}$ & $\begin{array}{l}\text { LGU, other } \\
\text { financing } \\
\text { institutions }\end{array}$ & March 2018 \\
\hline
\end{tabular}




\begin{tabular}{|c|c|c|c|c|}
\hline $\begin{array}{l}\text { Improvement of } \\
\text { the method of } \\
\text { production }\end{array}$ & $\begin{array}{l}\text { To improve method of } \\
\text { production from manual to } \\
\text { mechanize thus improve } \\
\text { the quantity and efficiency } \\
\text { of the production }\end{array}$ & $\begin{array}{l}\text { 1. Conduct a research studies related } \\
\text { to the production, machines and } \\
\text { equipments. } \\
\text { 2. Giving financial subsidies from the } \\
\text { LGU to support the project }\end{array}$ & $\begin{array}{l}\text { DOST, DA, } \\
\text { LGU and } \\
\text { other } \\
\text { financing } \\
\text { institutions }\end{array}$ & March 2018 \\
\hline $\begin{array}{c}\text { Product } \\
\text { development }\end{array}$ & $\begin{array}{l}\text { To improve the product } \\
\text { quality and design thus } \\
\text { improve the product } \\
\text { competitiveness. }\end{array}$ & $\begin{array}{l}\text { 1. Conduct a product development } \\
\text { study to improve the quality and } \\
\text { design of the products } \\
\text { 2. Giving seminars and trainings to } \\
\text { manufacturers for the } \\
\text { implementation of the results of the } \\
\text { study }\end{array}$ & $\begin{array}{c}\text { DTI, NEUST, } \\
\text { and LGU }\end{array}$ & March 2018 \\
\hline
\end{tabular}

This action plan was based on the identified problems of the industry and the present production management practices of the manufacturers. Generally, plans need collaborative effort of manufacturers, Local Government Unit of San Antonio, DTI and other financing institutions. These plans and strategies will further improve the present condition of the industry and can provide employment for unemployed citizens and out-of-school youth of the municipality.

\section{REFERENCES}

[1] American Institute for learning stages of life, (2012) retrieved from http://www.institute4learning.com/stages_of_life.php

[2] Aydemir, Y. Gungen, A.C., Coban H. (2015). Hypersensitivity pneumonitis caused by the broom grass (Calluna vulgaris). Respiratory Medicine Case Reports, $\quad 15(2), \quad 135 \quad$ - 137. Doi:10.1016/j.rmcr.2015.06001A

[3] Cabangbang, M.V., Baradas F., and Cabrera, A. (2007). Developments in Agroforestry Research, Philippine Council for Agriculture, Forestry and Natural Resources Research and

Development. Los Baños, Laguna: PCARRD, 2007. 486p Book Series No. 160.

[4] Elizabeth Cleaning services, 2012 Retrieved from http://tagaloglang.com/filipino-brooms/

[5] Ella,A.B., Domingo, E.P. (n.d). Tiger Grass Farming and Broom Making (2nded.).

[6] Galang, Armand. 'Nueva Ecija town features 'tambo' in patron saint's feast." Philippine Daily Inquirer, 16 January 2012: 1. Print.

[7] How to make broom breed tiger grass or walistambo, (2011)retrieved from http://www.pinoyentrepreneur.com/how-to- makebroom-tiger-grass-or-walis-tambo

[8] Propagation management and harvesting of tiger grass farming in the highlands, (n.d) retrieved from http://www.pcaarrd.dost.gov.ph/home/momentum/afin /index.php?option=com_content\&viewarticle $\&$ id $=405$ :propagation-management-and-harvesting-of-tigergras s-in-the-highlands \& catid=87\&Itemid $=2$
[9] Rostgaard Nielsen, L., Brandes, U., Dahl Kjaer, E. and Fjellheim, S. (2017), Introduced Scotch broom (Cytisusscoparius) invades the genome of native populations in vulnerable heathland habitats, MolEcol, 25:2790-2804.doi:10.1111/mec.13666

[10] Shackleton, S., Campbell, B., Sitsika, H. (2008).Links between the Local Trade in Natural Products, Livelihoods and Poverty Alleviation in a Semiarid Region of South Africa. World Development, 36(3), 505-526 